\title{
The Effect of Iron Supplements on Lung Vital Capacity in Soccer School
}

\author{
Pudia M. Indika \\ ${ }^{l}$ Faculty of Sport Science, Universitas Negeri Padang, Padang, Indonesia \\ *Corresponding author. Email: pudia.dr@fik.unp.ac.id
}

\begin{abstract}
Physical exercise on high frequency and intensity requires cardiopulmonary endurance. Lung vital capacity is ability of lung to maximum respiration. Oxygen in the air can be distributed if it has iron minerals in hemoglobin. Severe physical exercise interferes with the absorption of iron minerals. The research aims to determine the given effect of iron supplements to lung vital capacity of soccer athletes. This is pre-experimental study which uses one group pretest posttest design with analysis of data uses simple regression. Primary data collected from spirometry tests 16 athletes of soccer. Iron minerals supplements given once daily for 30 days. Data analysis showed iron supplements was statistically significant to lung vital capacity with $t$ value $=6.437$, a significance value $=0.000$, and probability value $=0.05$. Iron minerals needs can be obtained from supplements. Adequacy of iron minerals in the body influences changes in lung vital capacity. Iron minerals contained in hemoglobin can bind oxygen and formation of new red blood cells.
\end{abstract}

Keywords: Llung vital capacity, iron minerals, Iron supplements

\section{INTRODUCTION}

Exercise with severe intensity and a long time can reduce red blood cells (RBC) levels and associated with anemia [1]. Athlete nutrition must always be calculated correctly based on individual characteristics[2]. Sports nutrition is influenced by nutritional intake and management of food. Nutritional intake is influenced by the quality and quantity of food[3]. In addition to carbohydrates, protein and lipid, the man needed vitamins and minerals like iron[4]. Iron is very important as a cofactor for oxygen transport, respiration, amino acids, sulfite metabolism, retinol, alcohol and lipids, as well as various other redox reactions. A minimum dose of $8 \mathrm{mg}$ of iron is required to maintain adequate storage for people consuming mixed diets[5]. Most of the iron in the blood is contained in hemoglobin red blood cells amounting to around 400-600 mg/l[5]. The good iron stores are reflected in the concentration of ferritin in the blood[6]. Levels range of normal ferritin for males are 12 to 300 nanograms per milliliter of blood $(\mathrm{ng} / \mathrm{mL})$ and females are 12 to $150 \mathrm{ng} / \mathrm{mL}$ [7].

the results of research conducted by Nabhan D et al. that male athletes have a lower distribution of serum ferritin values compared to normative data in healthy men, with $15 \%$ of male athletes having suboptimal serum ferritin status. The distribution of serum ferritin values in elite female athletes does not differ from the population values, but about half of female athletes have iron deficiency[8]. The athletes need extra iron of supplements.

Iron is an essential mineral component of hemoglobin in red blood cells which is needed for oxygen delivery throughout the body as well as other roles in metabolism, respiration, and immune function. [9]. Sports with regular exercise will improve breathing abilities including maximum oxygen volume and vital capacity[10]. The vital capacity is total of the inspired reserve volume, the expiratory reserve volume and the tidal volume. It is also the maximum volume of air a human can inhale and exhale in one breath. Maintaining the ideal vital capacity is important because the greater the vital capacity, the better oxygen levels can be maintained. Oxygen levels are very important for maintaining the function of most tissues in the human body, especially brain tissue [11].

Physical training is the basic ability of an athlete before exploring sport skills. Physical exercise must attention to the frequency, intensity, time and type of training provided. The goal to be achieved in training is the maximum ability of body organs to be able to adapt to the burden that is given gradually. The ability of the cardiopulmonary endurance in minimizing the use of oxygen in strenuous physical 
exercise in order to fulfill oxygenation to the tissues[12]. Lung vital capacity is the maximum amount of air a person can expel from the lungs, after first filling the lungs to the maximum and then releasing as much $( \pm 4600$ milliliters $)$. Lung volume and capacity $20-20 \%$ greater at people who are big and athletic compared to people who are small and astenis. Factors that can affect the vital capacity of the lungs are body shape, age, sex, physical exercise and pregnancy. Oxygen consumption and total lung ventilation increase about 20 times between rest and exercise with maximum intensity in a well-trained athlete[13].

Rajawali soccer school is one of the clubs located in the city of Padang. The exercises are carried out 4 - 5 days which are done every week. Exercise can be aerobic and anaerobic in order to increasing the ability physical fitness and playing skills. the performance of Rajawali athlete has decreased, the probable cause is inadequate nutrition with the training load given so as to cause a decrease in hemoglobin. iron supplementation will increase hemoglobin levels which might affect the vital capacity of the athlete's lungs.

\section{METHODS}

Experimental research with one group pretestposttest design[14]. The sample consists of a total of 16 athletes from the Padang Rajawali football club. The study was conducted in the city of Padang. Each sample is given Fe tablets for 30 days. Before consuming the supplement, the sample was tested for vital lung capacity using a spirometer (pretest). After 30 days the lung's vital capacity was measured again using a spirometer (posttest). Spirometry testing was carried out three times and the results were taken from the highest value. Data analysis using simple regression is the analysis of the effect of $\mathrm{X}$ variable on variable $\mathrm{Y}[15]$.

\section{RESULT AND DISCUSSION}

Result

a. Test of vital capacity (VC) before treatment

The vital capacity is as follows :

Table 1. Frequency distribution of vital capacity (pretest)

\begin{tabular}{|c|l|c|c|}
\hline No & Classification & Interval & Frequncy \\
\hline 1 & Good & $3,91-4,47$ & 5 \\
\hline 2 & Average & $3,05-3,90$ & 8 \\
\hline 3 & Less & $2,48-3,04$ & 3 \\
\hline
\end{tabular}

Based on the distribution table, the results obtained by Rajawali soccer club athletes still have the most $\mathrm{VC}$ in the average classification of 8 people $(50 \%)$ b. Test of vital capacity after treatment

The vital capacity is as follows :

Table 2. Frequency distribution of vital capacity (posttest)

\begin{tabular}{|c|l|c|c|}
\hline No & Classification & Interval & Frequncy \\
\hline 1 & Good & $3,91-4,47$ & 5 \\
\hline 2 & Average & $3,05-3,90$ & 9 \\
\hline 3 & Less & $2,48-3,04$ & 2 \\
\hline
\end{tabular}

Based on the distribution table above, the results obtained Rajawali soccer club athletes after being given the most $\mathrm{Fe} \mathrm{VC}$ tablets in the average classification numbered 9 people $(56.2 \%)$.

c. Effect of iron supplements administration on vital capacity

Results of data analysis can be seen in the following table:

\begin{tabular}{|l|l|r|r|c|l|l|}
\hline \multirow{2}{*}{$\begin{array}{c}\text { Mode } \\
1\end{array}$} & & \multicolumn{2}{|c|}{$\begin{array}{c}\text { Unstandardized } \\
\text { Coefficients }\end{array}$} & $\begin{array}{c}\text { Standardize } \\
\mathrm{d} \\
\text { Coefficient } \\
\text { s }\end{array}$ & & \\
\cline { 2 - 7 } & & $\mathrm{B}$ & $\begin{array}{c}\text { Std. } \\
\text { Error }\end{array}$ & Beta & $\mathrm{t}$ & Sig. \\
\hline 1 & $($ Constant & 844.45 & 445.88 & & 1.89 & $\begin{array}{l}.07 \\
9\end{array}$ \\
\cline { 2 - 8 } & Pretest & .787 & .122 & .865 & $\begin{array}{l}6.43 \\
7\end{array}$ & $\begin{array}{l}.00 \\
0\end{array}$ \\
\hline
\end{tabular}

From the above output we can know the value of $\mathrm{t}$ count $=6,437$ with a significance value of $0,000<0.05$, which means that there is a significant influence (significance) of variable X (iron supplementation) on the participation variable (Vital Capacity).

The results showed that iron supplementation had an influence on vital capacity (VC). Supplement used in the study contained Iron fumarate $\left(\mathrm{Fe}^{2+}\right) . \mathrm{Fe}^{2+}$ is a simple form of iron that will be absorbed by the duodenum by cytochrome B, and will bind with a divalent metal carrier in the membrane to enter the erythrocytes. To be able to synthesize with hemoglobin, $\mathrm{Fe}^{2+}$ must change in ferry form $\left(\mathrm{Fe}^{3+}\right)$ after passing through erythrocytes [16].

\section{Discussion}

Iron Fumarate is a form of fumarate salt from mineral iron. Administration of iron fumarate results in an increase in serum iron concentrations, which are then assimilated into hemoglobin, necessary for oxygen transport, or trapped in reticuloendothelial cells for storage. This agent is used as a food supplement, and to prevent or treat syndromes related to iron deficiency[17]. Iron deficiency in sports often occurs in accordance with the stages of iron deficiency. Any type of exercise will also cause some kind of inflammation in the body, because the inflammation repair mechanism is the basis of exercise adaptation. The inflammatory response depends on the type, intensity and duration of training. Several signs of iron metabolism are affected by inflammation, because the release of iron is part of the acute phase response. Regarding iron metabolism, there 
is intense exercise shown to cause an increase in different hepcidins. This causes inhibition of iron absorption, impaired transfer of iron from macrophages to erythroblasts and possibly can lead to iron deficiency. Hepcidin synthesis, on the other hand, is suppressed by erythropoetic activity and anemia. This allows for increased intestinal absorption and iron utilization from macrophages and hepatocytes under conditions of increased iron loss. The main mechanism by which exercise increases iron loss is explained by intestinal microiscaemia during excessive exercise [18].

Research conducted by Zulfachri (2013) explains that there is an effect of iron supplementation on hemoglobin levels after maximum physical activity. This supplement is a substance that contains a lot of iron which plays a role in the formation of hemoglobin. The oxygen binding capacity of hemoglobin will increase so that the formation of energy will be relatively greater. The transport of oxygen to the tissues depends on the amount of oxygen entering the lungs, blood flow and blood transport capacity. The amount of oxygen in the blood is determined by the amount of dissolved oxygen, the level of hemoglobin in the blood and the affinity of hemoglobin with oxygen. [19].

the transport of oxygen to tissues depends on the amount of oxygen that enters the lungs, blood flow and blood transport capacity. The amount of oxygen in the blood is determined by the amount of dissolved oxygen, the level of hemoglobin in the blood and the affinity of hemoglobin for oxygen. $\mathrm{O}_{2}$ will be bound by hemoglobin in the blood and transported to body cells through the blood vessel, while $\mathrm{CO}_{2}$ will be released. When exercise automatically breath will be faster to meet oxygen needs. People who have a large vital capacity will be more fortunate because the breathing frequency is not too fast. Research conducted by Herina Zufrianingrum was obtained based on the results of multiple correlations proving that together there is a significant relationship between hemoglobin and vital lung capacity and cardiorespiratory resistance of $44 \%$ with a sign value of 0.007 . The more hemoglobin and the greater the vital capacity of a person will greatly assist in the large volume of oxygen transport into the body [20].

\section{CONCLUSION}

Adequacy of iron minerals in the body influences changes in lung vital capacity. Iron minerals contained in hemoglobin can bind oxygen and formation of new red blood cells

\section{REFERENCES}

[1] Che Hung Liu. et al. The changes of red blood cell viscoelasticity and sports anemia in male 24hr ultra-marathoners. JCMA 2017.doi: https://doi.org/10.1016/j.jcma.2017.09.011
[2] Sorrenti V.et.al. Personalized sports nutrition: Role of nutrients in athletic performance. Sports, Exercise, and Nutritional Genomics. . Elsevier 2019; doi https://doi.org/10.1016/B978-0-12816193-7.00018-X

[3] Marina D.et.al. Pedoman Gizi Olahraga Prestasi. Kementerian Kesehatan RI 2014;p.3-5

[4] Anggri,Pudia M Indika. Pengaruh pemberian suplemen mineral zat besi (fe) terhadap Kadar hemoglobin (hb) atlet sepakbola rajawali kota Padang. Jurnal Stamina Vol 2(2).2019. doi https://doi.org/10.24036/jst.v2i2.136

[5] Kohlmeier M. Minerals And Trace Elements. Nutrient Metabolism(2nd ed).2015,p 697 -709; doi https://doi.org/10.1016/B978-0-12-3877840.00011-0

[6] Brittenham GM.et.al. Circulating non transferin bound iron after oral adminstration of supplemental and fortitification doses of iron to healthy women: a randomized study. Am. J.Clin. Nutr. 100, 813-820

[7] Stöppler MC. Ferritin blood test facts. . https://www.medicinenet.com/ferritin_blood_test /article.htm

[8] Nabhan D.et al. Serum Ferritin Distribution in Elite Athletes. JSAMS 2019. Doi https://doi.org/10.1016/j.jsams.2019.12.027

[9] Rubeor A. et al. Does iron supplementation improve performance in iron-deficient nonanemic athletes? Sports Health 2018;10(5):400-5.

[10] B Lazovic.et.al. Comparison of lung diffusing capacity in young elite athletes and their counterparts. Pneumologia 2017. Doi https://doi.org/10.1016/j.rppnen.2014.12.003

[11] Irzaldy A; Wiyasihati S.I; Purwanto B. Lung Vital Capacity of Choir Singers and Nonsingers: A Comparative Study. Journal of Voice 2016; Vol 30(6);p.717-20. Doi https://doi.org/10.1016/j.jvoice.2015.08.00.

[12] Giriwijoyo S, Sidik D, 2012. Ilmu Kesehatan Olahraga. Remaja Rosdakarya. Bandung.

[13] Hall J E. Fisiologi Kedokteran, Editor Widjajakusumah, Tanzil. Edisi 12, 2014.Elsevier, Singapore

[14] Creswell J.W. Resesarch Design Qualitative, Quantitative and Methods Appraoaches. Fourth Edition.2014. SAGE Publication

[15] Dahlan M.S. Statistik untuk Kedokteran dan Kesehatan. Ed. 4.2009. Salemba Medika

[16] Barbara J.B. Hematologi : Kurikulum Inti.2014. EGC

[17] Degerud EM.et.al. Bioavailability of iron, vitamin A, zinc, and folic acid when added to condiments and seasonings. Annals of the New 
York Academy of Sciences 2015 Nov; 1357(1):29-42

[18] Clénin G.E.at.al. Iron deficiency in sports definition, influence on performance and therapy. Swiss Med Wkly 2015. Doi https://doi.org/10.4414/smw.2015.14196

[19]Zulfachri. Pengaruh Pemberian Sangobion Terhadap Kadar Hemoglobin Setelah Melakukan Aktifitas Fisik Maksimal Pada Mahasiswa Ikor. Jurnal Ilmu Keolahragaan Vol 12(1) 2013

[20] Zufrianingrum H. Hubungan antara kadar hemoglobin dan kapasitas Vital paru dengan daya tahan kardiorespirasi siswa Yang mengikuti ekstrakurikuler bolabasket Di smp negeri 1 jetis kabupaten bantul. UNY 2013 